\title{
Effect of temperature and precipitation on nitrate leaching from organic cereal cropping systems in Denmark
}

\author{
Mohamed Jabloun $^{\mathrm{a}, \mathrm{b}, \mathrm{c}, *}$, Kirsten Schelde ${ }^{\mathrm{a}}$, Fulu Tao ${ }^{\mathrm{c}, \mathrm{d}}$, Jørgen E. Olesen ${ }^{\mathrm{a}, \mathrm{b}}$ \\ a Aarhus University, Department of Agroecology, Blichers Allé 20, PO Box 50, 8830 Tjele, Denmark \\ ${ }^{\mathrm{b}}$ Sino-Danish Centre for Education and Research (SDC), Niels Jensens Vej 2, 8000 Aarhus C, Denmark \\ ' Institute of Geographical Sciences and Natural Resources Research, Chinese Academy of Sciences, 11A, Datun Road, Chaoyang District, Beijing 100101, \\ China \\ d Plant Production Research, MTT Agrifood Research Finland, FI-50100 Mikkeli, Finland
}

\section{A R T I C L E I N F O}

\section{Article history:}

Received 4 April 2014

Received in revised form

19 September 2014

Accepted 22 September 2014

Available online 10 October 2014

\section{Keywords:}

Nitrogen

Leaching

Organic farming

Wheat

Barley

\begin{abstract}
A B S T R A C T
The effect of variation in seasonal temperature and precipitation on soil water nitrate $\left(\mathrm{NO}_{3}-\mathrm{N}\right)$ concentration and leaching from winter and spring cereals cropping systems was investigated over three consecutive four-year crop rotation cycles from 1997 to 2008 in an organic farming crop rotation experiment in Denmark. Three experimental sites, varying in climate and soil type from coarse sand to sandy loam, were investigated. The experiment included experimental treatments with different rotations, manure rate and cover crop, and soil nitrate concentrations was monitored using suction cups. The effects of climate, soil and management were examined in a linear mixed model, and only parameters with significant effect $(P<0.05)$ were included in the final model. The model explained $61 \%$ and $47 \%$ of the variation in the square root transform of flow-weighted annual $\mathrm{NO}_{3}-\mathrm{N}$ concentration for winter and spring cereals, respectively, and $68 \%$ and $77 \%$ of the variation in the square root transform of annual $\mathrm{NO}_{3}-\mathrm{N}$ leaching for winter and spring cereals, respectively. Nitrate concentration and leaching were shown to be site specific and driven by climatic factors and crop management. There were significant effects on annual $\mathrm{N}$ concentration and $\mathrm{NO}_{3}-\mathrm{N}$ leaching of location, rotation, previous crop and crop cover during autumn and winter. The relative effects of temperature and precipitation differed between seasons and cropping systems. A sensitivity analysis revealed that the predicted $\mathrm{N}$ concentration and leaching increased with increases in temperature and precipitation.
\end{abstract}

(c) 2014 Elsevier B.V. All rights reserved.

\section{Introduction}

In Europe, and specifically in Denmark, agriculture is generally considered as the main source of nitrate leaching to ground and surface waters (Askegaard et al., 2005). The loss of nitrogen (N) to aquifers and surface waters is an inevitable consequence of intensively managed agricultural systems due to the use of $\mathrm{N}$ fertilizers (Hansen et al., 2000a; Nielsen et al., 2012) and soil cultivation (Askegaard et al., 2011). In Denmark, agriculture accounted for approximately $81 \%$ of the $\mathrm{N}$ load to Danish watercourses and about $70 \%$ of the $\mathrm{N}$ inputs to the sea via water courses and atmospheric deposition during 1989-1996 (Hansen et al., 2000a). However, the nitrate leaching from agriculture in Denmark has been substantially reduced through governmental regulations setting standards

\footnotetext{
* Corresponding author at: Aarhus University, Department of Agroecology, Blichers Allé 20, PO Box 50, 8830 Tjele, Denmark. Tel.: +45 87157795.

E-mail address: Mohamed.Jabloun@agrsci.dk (M. Jabloun).
}

for rates of manure and fertilizer application, use of catch crops (Kronvang et al., 2008) and encouraging additional measures such as organic farming (Askegaard et al., 2005). However, despite the decrease in $\mathrm{N}$ concentrations observed in surface water (Jeppesen et al., 2011) further reductions in $\mathrm{N}$ leaching are needed to achieve the goals of good ecological status of the aquatic environment as required by the EU Water Framework Directive.

Understanding the potential impacts of climate change on crop productivity, the hydrological and $\mathrm{N}$ cycles and fluxes is essential for ensuring food security and guaranteeing the sustainability of future water resources. Such impacts are well recognized and have been widely reported over the recent decades (Ritcey and Wu, 1999; Olesen et al., 2000a; Orlandini et al., 2008; Bindi and Olesen, 2011; Hatfield and Singer, 2011; Tao and Zhang, 2011; Trnka et al., 2011). Changes in the mean and variability of temperature and rainfall patterns have direct effects on crop yields. Changes in atmospheric $\mathrm{CO}_{2}$ concentration and indirect effects through changes of the hydrological cycle also affect yields as well as biological and chemical transformations of carbon (C) and $\mathrm{N}$ in 
soils with associated leaching or gaseous losses of $\mathrm{N}$ (Allen and Ingram, 2002; Olesen et al., 2011). As the flux of soil mineral $\mathrm{N}$ is largely influenced by precipitation events the risk of $\mathrm{N}$ losses through leaching, and possibly $\mathrm{N}_{2} \mathrm{O}$ emissions, may increase with increased precipitation. Increased $\mathrm{N}$ leaching during winter and early spring might also reduce $\mathrm{N}$ availability to the succeeding crop. Furthermore, the rate of soil organic matter (SOM) mineralization, which depends on the nature and abundance of SOM and on soil temperature, moisture and microbial activity, is expected to increase with increasing temperature (Thomsen et al., 2010; Contosta et al., 2011). Decomposition of SOM will lead to the buildup of inorganic $\mathrm{N}$ in the soil, resulting in an increased risk of nitrate $\left(\mathrm{NO}_{3}-\mathrm{N}\right)$ leaching (Olesen et al., 2004; Thomsen et al., 2010) and a decrease in SOM, which in turn can reduce soil fertility affecting crop yields and $\mathrm{N}$ cycling. It is therefore critical to understand how soil $\mathrm{N}$ cycling and losses may be affected by climate change.

Several studies have addressed the potential effects of climate change on $\mathrm{N}$ leaching. Most of these studies are model based. For instance, Olesen et al. (2007a) modelled the impact of climate change on winter wheat yield and nitrate leaching by applying different impact models at site, regional and continental scales under a range of climate change scenarios. They projected a spatial pattern of changes in nitrate leaching over Europe for the period 2071-2100 showing a patchy variation indicating that local factors could be affecting $\mathrm{N}$ leaching under climate change. Furthermore, Patil et al. (2012) used the FASSET model to evaluate the sensitivity of winter wheat yield and soil $\mathrm{N}$ losses to stepwise changes in means and variances of climatic variables in Denmark. They showed an increase in $\mathrm{N}$ leaching from winter wheat with increasing temperature, in particular for sandy loam soil at temperature increases of above $2{ }^{\circ} \mathrm{C}$. They also found higher simulated soil mineral $\mathrm{N}$ concentrations at crop harvest in summer at higher temperatures and, therefore, higher risk of $\mathrm{NO}_{3}-\mathrm{N}$ leaching during autumn and winter, which was ascribed to less crop $\mathrm{N}$ uptake and increased mineralization of soil organic matter.

In 1997, an organic arable crop rotation experiment was initiated at three locations in Denmark (Olesen et al., 2000b). The experimental treatments, the applied crop management, and the three experimental locations reflect well the range of arable organic farming systems as well as the range of soil types and climatic variation in Denmark. In the 1st four-year cycle of the rotations, Askegaard et al. (2005) showed significant effects of location (soil types and climate) and catch crops and no effect of crop rotation design and manure application on $\mathrm{N}$ leaching. After three consecutive four-year crop rotations cycles, Askegaard et al. (2011) identified autumn crop and soil management as the main determinant of $\mathrm{N}$ leaching, since surplus rainfall during autumn and winter causes soil mineral $\mathrm{N}$ to leach, and the concentration of soil mineral $\mathrm{N}$ will to a large extent be determined by plant uptake during autumn. In these two studies, the possible effects of the climatic factors on $\mathrm{N}$ leaching were not explicitly investigated. Therefore, we used data from this long-term crop rotation experiment to analyze the effect of the seasonal change in the climate variables (i.e. air temperature and precipitation) on $\mathrm{NO}_{3}-\mathrm{N}$ leaching and concentration in winter and spring cereals.

We hypothesize that higher air temperature will increase the risk of $\mathrm{N}$ leaching through increased soil $\mathrm{N}$ mineralization of soil organic matter and crop residues leading to higher soil mineral $\mathrm{N}$. As the flux of nitrate $\mathrm{N}$ out of the root zone is largely influenced by the difference between precipitation and evapotranspiration, we further hypothesize that $\mathrm{NO}_{3}-\mathrm{N}$ leaching will increase with increasing autumn and winter precipitation. The objective of our study was therefore (i) to estimate the effect of air temperature and precipitation on $\mathrm{NO}_{3}-\mathrm{N}$ concentrations and leaching from cultivation of winter and spring cereals grown in the long-term organic farming experiment, and (ii) to assess how $\mathrm{N}$ leaching and
$\mathrm{N}$ concentration from cereal cropping systems in Denmark will respond to changes in temperature and precipitation using the developed empirical models.

\section{Materials and methods}

\subsection{Experimental sites}

This study used data from a long-term organic farming crop rotation experiment that included three treatment factors and three consecutive four-year crop rotation cycles from 1997 to 2008. The experiment is described in detail by Olesen et al. (2000b) and Askegaard et al. (2011); therefore, only a brief outline will be given here. The experiment was conducted at three locations representing different soil types and climate in Denmark (Olesen et al., $2000 \mathrm{~b})$. Jyndevad $\left(54^{\circ} 54^{\prime} \mathrm{N}, 9^{\circ} 08^{\prime} \mathrm{E}\right)$ is located in southern Jutland on coarse sand, Foulum $\left(56^{\circ} 30^{\prime} \mathrm{N}, 9^{\circ} 34^{\prime} \mathrm{E}\right)$ is located in Central Jutland on loamy sand, and Flakkebjerg $\left(55^{\circ} 19^{\prime} \mathrm{N}, 11^{\circ} 23^{\prime} \mathrm{E}\right)$ in Western Zealand on sandy loam. Prior to the initiation of the experiment, in autumn 1996, a characterization of the soil at the experimental sites was conducted. Sixteen soil samples were randomly taken in each plot to $1 \mathrm{~m}$ depth to determine soil texture and organic matter content. The depth of the A horizon was determined as an average of 16 soil cores for each plot (Djurhuus and Olesen, 2000). Site details are given in Table 1 . The content of topsoil SOM was least at Flakkebjerg despite the higher clay content, presumably as a result of previous decades of intensive arable crop cultivation with little organic inputs. The plant available soil water was 7.6, 19.3 and $14.2 \%(\mathrm{v} / \mathrm{v})$ in the upper $1 \mathrm{~m}$ of the soil profile for Jyndevad, Foulum and Flakkebjerg, respectively (Askegaard et al., 2005). The larger clay content may have caused deeper rooting at Flakkebjerg and thus larger total effective capacities for plant-available water. There were no marked slopes or other elevation effects at Jyndevad, whereas the elevation varied about $3 \mathrm{~m}$ and $8 \mathrm{~m}$ across the site at Foulum and Flakkebjerg, respectively.

\subsection{Experimental treatments}

Three experimental factors were included in a factorial design: (1) crop rotation with proportion of grass-clover and pulses (pea (Pisum sativum L.), lupin (Lupinus angustifolius L.) or faba bean (Vicia faba L.) ) in the rotation, (2) with (+CC) and without ( $-\mathrm{CC}$ ) catch crop, and (3) with $(+\mathrm{M})$ and without $(-\mathrm{M})$ animal manure applied as slurry. At each location the experiment had two replicates laid out in two separate blocks. Each block was further subdivided into two sub-blocks to better cover soil variation (Askegaard et al., 2005). At each location, all courses in each rotation were represented every year. The experimental plots were randomized within sub-blocks and were managed individually when necessary.

The three 4-year crop rotations (R1, R2 and R4) are shown in Table 2. These rotations differed in the use of a grass-clover green manure, which was present in rotations R1 and R2, but not in R4. Rotation R4 was not initially included at Jyndevad, because the coarse sandy soil was considered unsuitable for organic arable rotations without green manures. However, in 2005 changes were made to the experimental treatments, and the R1 rotation at Jyndevad was converted to an R4 rotation.

Ploughing before sowing of spring cereals was mostly carried out in spring at Jyndevad and Foulum and in November to December at Flakkebjerg. The grass-clover was spring-ploughed in R1 and followed by spring wheat (Triticum aestivum L.), and autumn-ploughed in R2, and followed by winter wheat in the two first cycles. In the 3 rd cycle, the grass-clover was spring-ploughed at Jyndevad and Foulum, and autumn ploughed at Flakkebjerg prior to growing potato (Solanum tuberosum L.). Where present, catch crops 
Table 1

Soil characteristics for the three experimental sites (Djurhuus and Olesen, 2000; Hansen et al., 2000b). Soil texture and bulk density is shown for the topsoil (0-25 cm).

\begin{tabular}{|c|c|c|c|c|}
\hline \multicolumn{5}{|l|}{ Location } \\
\hline & & Jyndevad & Foulum & Flakkebjerg \\
\hline Texture class & & Coarse sand & Loamy sand & Sandy loam \\
\hline Coarse sand (200-2000 mm) & $\mathrm{g} \mathrm{kg}^{-1}$ & 731 & 272 & 229 \\
\hline Fine sand $(20-200 \mathrm{~mm})$ & $\mathrm{g} \mathrm{kg}^{-1}$ & 180 & 470 & 474 \\
\hline Silt $(2-20 \mathrm{~mm})$ & $\mathrm{g} \mathrm{kg}^{-1}$ & 24 & 133 & 124 \\
\hline Clay $(<2 \mathrm{~mm})$ & $\mathrm{g} \mathrm{kg}^{-1}$ & 45 & 88 & 155 \\
\hline Soil organic matter & $\mathrm{g} \mathrm{kg}^{-1}$ & 20 & 38 & 17 \\
\hline Soil organic $C$ & $\mathrm{~g} \mathrm{~kg}^{-1}$ & 11.7 & 22.9 & 10.1 \\
\hline \multicolumn{5}{|l|}{ Depth of A horizon } \\
\hline Minimum & $\mathrm{cm}$ & 26.8 & 34.8 & 36.6 \\
\hline Maximum & $\mathrm{cm}$ & 34.1 & 92.9 & 72.3 \\
\hline Bulk density & $\mathrm{Mg} \mathrm{m}^{-3}$ & 1.47 & 1.41 & 1.56 \\
\hline
\end{tabular}

were undersown in the cereals or pulse crops in spring. The catch crops of the organic cropping systems were either pure stands of perennial ryegrass (Lolium perenne L.) or a mixture of perennial ryegrass, chicory (Cichorium intybus L.), white clover (Trifolium repens L.) and red clover (Trifolium pratense L.), and the grass-clover ley was a mixture of perennial ryegrass and white and red clover. In the rotations that included catch crops, the catch crop was incorporated into the soil by ploughing prior to sowing the next crop in the rotation.

All crop residues were left on the ground or incorporated into the soil after harvest. Cuttings of grass-clover in the $\mathrm{R} 2$ rotation $(2-5$ per season) were left on the soil, except for the $+\mathrm{M}-\mathrm{CC}$ treatment from 2005 onwards, were cuttings were removed. Weeds were controlled in all rotations by mechanical weed harrowing. Plots with presence of perennial weeds were harrowed in autumn in the -CC treatments and in some years in the $+\mathrm{CC}$ treatments immediately after harvest and a catch crop was re-sown after one week.

The plots receiving manure were supplied with anaerobically stored slurry at rates corresponding to approximately $40 \%$ of the $\mathrm{N}$ demand of the specific rotation. The $\mathrm{N}$ demand was based on a Danish national standard (Askegaard et al., 2011). The N demands from grass-clover and from grain legumes were set to nil. The amounts of $\mathrm{N}$ allocated to winter wheat were higher than in the spring cereals to allow for the higher $\mathrm{N}$ demand of the winter cereal (Table 2).

\subsection{Measurements and calculations}

Leaching of $\mathrm{N}$ was measured in selected plots. This included all plots that constituted field 1 in the rotations (Table 2) when the experiment was initiated in 1997. Additional measurements were carried out in the other plots at Foulum and Flakkebjerg in $\mathrm{R} 2 /-\mathrm{CC} /+\mathrm{M}$ and at Jyndevad in all $+\mathrm{M}$ treatments. Four porous ceramic suction cells per plot were installed at $80 \mathrm{~cm}$ depth at Jyndevad and at $100 \mathrm{~cm}$ depth at the other sites. Every one to four weeks, depending on site and precipitation, a suction of approximately $80 \mathrm{kPa}$ was applied three days prior to sampling. The samples were bulked with equal sample volume from each of the four replicates per plot before analyzing nitrate content. The water balance and hence water drained from the soil profile were calculated using the EVACROP model (Olesen and Heidmann, 1990) which requires daily precipitation, temperature and reference evapotranspiration. Before applying the EVACROP model, precipitation was corrected to ground level (Askegaard et al., 2011). Nitrate leaching was estimated using the trapezoidal rule (Lord and Shepherd, 1993), with the assumption that nitrate concentrations in the extracted soil water represent average flux concentrations.

For the current study, only data on winter cereals (winter wheat and winter rye (Secale cereale L.), 177 observations) and spring cereals (spring wheat, spring oat (Avena sativa L.) and spring barley

Table 2

Structure of the crop rotations and the crops considered in the current study (spring cereals in bold and winter cereals in bold italic)..

\begin{tabular}{|c|c|c|c|c|c|c|c|c|c|c|}
\hline \multicolumn{2}{|l|}{ Crop rotations } & \multicolumn{3}{|l|}{$\mathrm{R} 1$} & \multicolumn{3}{|l|}{$\mathrm{R} 2$} & \multicolumn{3}{|l|}{$\mathrm{R} 4$} \\
\hline Cycles & Field no. & Crop & $\mathbf{M}^{1}$ & $\mathrm{CC}^{2}$ & Crop & $M^{1}$ & $\mathrm{CC}^{2}$ & Crop & $\mathbf{M}^{1}$ & $\mathrm{CC}^{2}$ \\
\hline \multirow[t]{4}{*}{ 1st cycle $1997-2000$} & 1 & S. barley:ley & 50 & & S. barley:ley & 50 & & Spring oat & 40 & +5 \\
\hline & 2 & Grass-clover & 0 & & Grass-clover & 0 & & Winter wheat & 70 & $+^{5}$ \\
\hline & 3 & Spring wheat & 50 & $+^{3}$ & Winter wheat & 50 & $t^{3}$ & Winter cereal & 70 & $+^{5}$ \\
\hline & 4 & Lupin & 0 & +4 & Peas/barley & 0 & +4 & Peas/barley & 0 & $+^{4}$ \\
\hline \multirow[t]{4}{*}{ 2nd cycle 2001-2004 } & 1 & S. barley:ley & 50 & & S. barley:ley & 50 & & Winter wheat & 50 & +4 \\
\hline & 2 & Grass-clover & 0 & & Grass-clover & 0 & & Spring oat & 50 & $++^{4}$ \\
\hline & 3 & Spring oat & 30 & $+^{3}$ & Winter cereal & 50 & $t^{3}$ & S. barley & 50 & $t^{3}$ \\
\hline & 4 & Peas/barley & 0 & +4 & Lupin & 0 & +4 & Lupin & 0 & \\
\hline \multicolumn{2}{|l|}{ Locations } & \multicolumn{3}{|l|}{ JY } & \multicolumn{3}{|l|}{ JY, FO, FL } & \multicolumn{3}{|l|}{$\mathrm{FO}, \mathrm{FL}$} \\
\hline \multirow[t]{4}{*}{ 3rd cycle 2005-2009 } & 1 & \multirow{4}{*}{\multicolumn{3}{|c|}{ Discontinued }} & S. barley:ley & 60 & & S. barley & 60 & +4 \\
\hline & 2 & & & & Grass-clover & 0 & & Faba bean & 0 & +4 \\
\hline & 3 & & & & Potato & 110 & & Potato & 110 & \\
\hline & 4 & & & & Winter wheat & 110 & +4 & Winter wheat & 110 & $+^{4}$ \\
\hline \multicolumn{5}{|l|}{ Locations } & JY, FO, FL & & & \multicolumn{3}{|l|}{ JY, FO, FL } \\
\hline
\end{tabular}


(Hordeum vulgare L.), 267 observations) were considered. The estimated daily $\mathrm{N}$ leaching was aggregated to annual values for the period from 1 April to $31 \mathrm{March}$, covering the main leaching period during autumn and winter. Annual flow-weighted $\mathrm{NO}_{3}-\mathrm{N}$ concentrations were also calculated as averages from 1 April to 31 March, for each cereal crop.

Air temperature and precipitation (uncorrected) were calculated as averages and cumulated values, respectively, on a seasonal timescale (four seasons; winter (Dec-Feb, DJF), spring (Mar-May, MAM), summer (Jun-Aug, JJA) and autumn (Sep-Nov, SON)). Summary statistics of the meteorological measurements are given in Table 3.

\subsection{Statistical analysis}

All statistical analyses and data exploration were conducted in $\mathbf{R}$ ( $R$ Core Team, 2012) as outlined by Zuur et al. (2010). The data were analyzed using an ANOVA-type mixed model, a statistical technique that allows including both fixed effects for describing the hypothesis to be tested and random effects for taking data structure into account (Piepho et al., 2003). The nlme package (Pinheiro et al., 2012) was used to examine the effects of crop management and seasonal changes in air temperature and precipitation on $\mathrm{NO}_{3}-\mathrm{N}$ concentration and leaching for the two cereal systems. Each dependent variable $\left(\mathrm{NO}_{3}-\mathrm{N}\right.$ concentration and $\mathrm{NO}_{3}-\mathrm{N}$ leaching) was square root-transformed to meet the normality and homoscedasticity assumptions of the mixed-effects model. Fixed effects included seasonal air temperature and precipitation and depth of the A horizon as continuous variables, and location, preceding crop, and winter crop cover as categorical variables.

Leaching year, blocks within location, sub-block within location, and plots within locations were considered as random effects. Leaching year was included to take into account the random effect of year, where effects beyond weather may have been affecting $\mathrm{N}$ flows and losses. All random effects were assumed to be independent and normally distributed with a mean of zero and constant variance. Manure application was not found to significantly affect $\mathrm{N}$ leaching nor $\mathrm{N}$ concentration in preliminary analyses; therefore, it was not included in the model.

Interactions among variables (e.g. interaction between air temperature and precipitation, catch crops and autumn weather, etc.) were found not to significantly affect $\mathrm{N}$ leaching or $\mathrm{N}$ concentration, and such interactions were thus not included in the model. The general form of the model thus becomes package nlme of the statistical software $\mathrm{R}$ (Pinheiro et al., 2012). All statistical tests for significance were performed at $P=0.05$ level.

\subsection{Climate sensitivity analyses}

To better understand the model prediction of $\mathrm{NO}_{3}-\mathrm{N}$ leaching and concentration responses to changes in seasonal temperature and precipitation, we performed ten climate change sensitivity analyses, with five levels of rainfall $(-40 \%,-20 \%$, baseline, $+20 \%$ and $+40 \%$ ) and five levels of temperature (baseline, $+1{ }^{\circ} \mathrm{C},+2{ }^{\circ} \mathrm{C},+3{ }^{\circ} \mathrm{C}$ and $+4{ }^{\circ} \mathrm{C}$ ). The observed weather data (temperature and precipitation) were perturbed using the delta change approach (Olesen et al., 2007a) to construct the weather files for the sensitivity analyses to be used with the regression models.

The simplified regression models, including all effects that were statistically significant were applied to the same data for each of the sensitivity analyses and the results were averaged for each cereal crop including all treatments, years and locations.

\section{Results}

Since the main objective of this study was to investigate the effect of seasonal temperature and precipitation change on $\mathrm{NO}_{3}-\mathrm{N}$ concentration and leaching in cereals grown in an organic cropping system, we focus the presentation on these effects. However, it is noteworthy that besides climate, nitrate concentration and leaching were shown to be driven also by site specific parameters, soil, cropping system and crop management. These effects were analyzed and discussed by Askegaard et al. (2005, 2011) and hence will not be presented here.

\subsection{Climate}

The average amount of cumulative precipitation varied little between seasons (Table 3). However, the seasonal precipitation showed large variations between sites and years. The mean annual precipitation differed substantially between the three locations (Fig. 1) with precipitation being highest at Jyndevad during autumn and winter (260 and $198 \mathrm{~mm}$, respectively) and least at Flakkebjerg (153 and $115 \mathrm{~mm}$ during autumn and winter, respectively). Seasonal mean air temperature also varied between sites and years, especially during autumn and winter with a difference between the mean value and the maximum value of about $3^{\circ} \mathrm{C}$ and $4{ }^{\circ} \mathrm{C}$,

$Y_{\mathrm{ply}}=\mu+\alpha_{\mathrm{a}} T_{\mathrm{a}}+\alpha_{\mathrm{w}} T_{\mathrm{w}}+\alpha_{\mathrm{sp}} T_{\mathrm{sp}}+\alpha_{\mathrm{s}} T_{\mathrm{s}}+\beta_{\mathrm{a}} P_{\mathrm{a}}+\beta_{\mathrm{w}} P_{\mathrm{w}}+\beta_{\mathrm{sp}} P_{\mathrm{sp}}+\beta_{\mathrm{s}} P_{\mathrm{s}}+$ Locat $_{\mathrm{l}}+$ Rotat $_{\mathrm{lpy}}+$ PreCrop $_{\text {ly }}+$

AWcover ${ }_{\mathrm{ly}}+\gamma H_{\mathrm{l}}+C_{\mathrm{lb}}+D_{\mathrm{ld}}+E_{\mathrm{lp}}+F_{\mathrm{ly}}$

where $Y_{\text {ply }}$ is the square root of the measured $\mathrm{NO}_{3}-\mathrm{N}$ concentration or $\mathrm{NO}_{3}-\mathrm{N}$ leaching from plot $\mathrm{p}$ at location 1 in year $\mathrm{y} ; \mathrm{a}, \mathrm{w}, \mathrm{sp}$, s denote autumn, winter, spring and summer for year $\mathrm{y}$; b and $\mathrm{d}$ are the level of block and sub-block; $\mu, T, P$, Locat, Rotat, PreCrop, $A W c o v e r$ and $H$ are the fixed effects of the general level, main effects of air temperature $\left({ }^{\circ} \mathrm{C}\right)$, precipitation $(\mathrm{mm})$, location, crop rotation, previous crop, autumn and winter crop cover, and depth of the A horizon (cm), respectively; $\alpha, \beta, \gamma$ are regression coefficients; $C_{\mathrm{lb}}, D_{\mathrm{lbf}}, E_{\mathrm{lp}}$ and $F_{\mathrm{ly}}$ are independent normally distributed random variables of block, sub-block, plot, and year within location with zero mean and variances $\sigma_{C}^{2}, \sigma_{D}^{2}, \sigma_{E}^{2}$, and $\sigma_{F}^{2}$, respectively.

In order to relate $\mathrm{NO}_{3}-\mathrm{N}$ concentration and leaching to the climatic parameters, the model described above was fitted to the square root transformed leaching data for winter and spring cereals separately. Secondly, each model was simplified in a stepwise manner by leaving out non-significant effects $(P>0.05)$. The parameters of the models were estimated by restricted maximum likelihood (REML). The fitting was performed using the function lme in the respectively. The variation during spring and summer was considerably lower. Mean temperature also varied between locations during autumn and winter with the lowest temperatures at Foulum (Fig. 1). During the study period, air temperature increased slightly in all seasons, except for winter, while precipitation showed no clear trend (data not shown).

\subsection{Nitrate concentrations}

Annual observed flow-weighted nitrate-N concentrations differed between years (Fig. 2a) mainly as a result of differences in precipitation that ranged from $752 \mathrm{~mm}$ in 2002/2003 to $1111 \mathrm{~mm}$ in 1997/1998, which affected drainage amounts (results not shown). Generally, nitrate concentrations were lowest in years with large precipitation, probably due to dilution. On average, nitrate concentrations were slightly higher from winter cereals (8.2 $\left.\mathrm{mg} \mathrm{L}^{-1}\right)$ compared to spring cereals (7.7 $\mathrm{mg} \mathrm{L}^{-1}$ ) (Table 4). 
Table 3

Summary of seasonal mean temperature and sum of precipitation for the period 1997 to 2008 at the three experimental locations.

\begin{tabular}{|c|c|c|c|c|c|c|c|c|}
\hline & \multicolumn{4}{|c|}{ Temperature $\left({ }^{\circ} \mathrm{C}\right)$} & \multicolumn{4}{|c|}{ Precipitation (mm) } \\
\hline & MAM & JJA & SON & DJF & MAM & JJA & SON & DJF \\
\hline Minimum & 5.5 & 13.7 & 7.5 & -2.4 & 70 & 83 & 51 & 58 \\
\hline Average & 7.5 & 16.0 & 9.5 & 1.5 & 137 & 225 & 210 & 171 \\
\hline Maximum & 8.6 & 17.9 & 12.6 & 5.2 & 271 & 354 & 370 & 353 \\
\hline Std. dev. & 0.7 & 0.9 & 0.9 & 1.6 & 41 & 55 & 71 & 75 \\
\hline
\end{tabular}
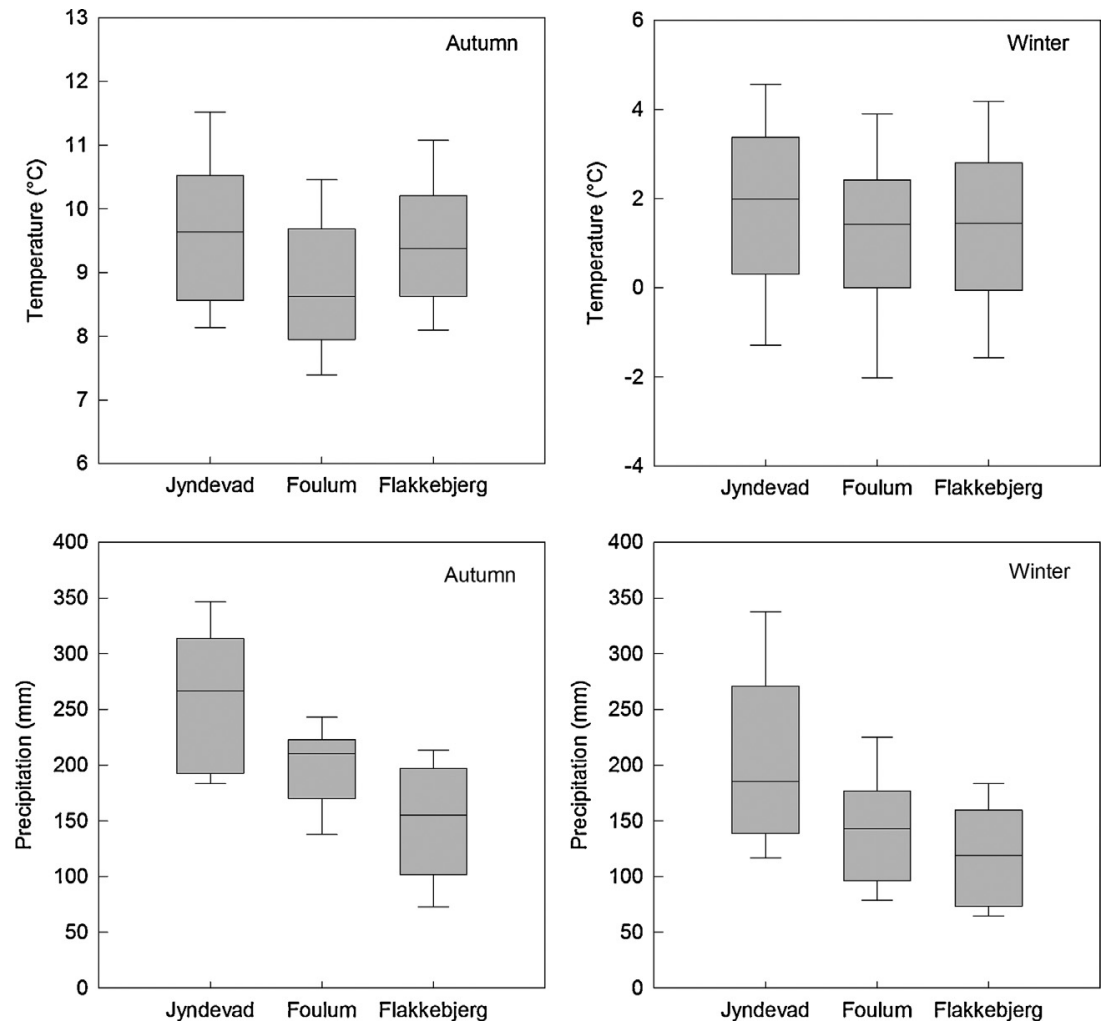

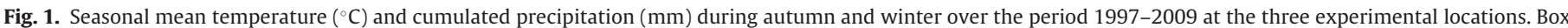

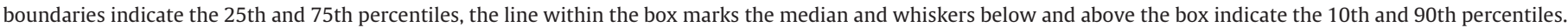

The effects of location, rotation, pre-crop and cover crop are shown in Table 5 relative to Jyndevad, R2, cereals and bare soil, respectively. Rotation and location had no significant effect on $\mathrm{NO}_{3}-\mathrm{N}$ concentration. However, the regression model suggested that $\mathrm{NO}_{3}-\mathrm{N}$ concentration was not only affected by the type of crops grown before the leaching season, but also by the autumn and winter management practices. The results showed that the use of catch crops, when averaged for all years, reduced $\mathrm{NO}_{3}-\mathrm{N}$ concentration significantly by 46 to $63 \%$ for winter cereals and by 27 to $61 \%$ for spring cereals compared to un-cropped soil (weeds or bare soil).
For both cropping systems, the results from the regression analyses showed that beside management practices, temperature and precipitation substantially affected the annual average $\mathrm{N}$ concentration (Table 5). In the case of winter cereals, precipitation during autumn and winter had significant $(P<0.001)$ but opposite effects on $\mathrm{N}$ concentration. Precipitation during autumn was found to increase nitrate concentration whereas winter precipitation reduced nitrate concentration. The same significant negative effect of precipitation during winter on $\mathrm{N}$ concentration was also found for spring cereals. For spring cereals, there was a strong

Table 4

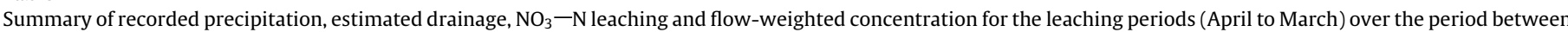
1997 and 2008 for spring and winter cereals.

\begin{tabular}{|c|c|c|c|c|c|}
\hline & & \multirow[t]{2}{*}{ Precipitation (mm) } & \multirow[t]{2}{*}{ Drainage (mm) } & \multicolumn{2}{|l|}{$\mathrm{NO}_{3}-\mathrm{N}$} \\
\hline & & & & Leaching $\left(\mathrm{kg} \mathrm{Nha}^{-1}\right)$ & Concentration $\left(\mathrm{mg} \mathrm{N} \mathrm{L}^{-1}\right)$ \\
\hline \multirow[t]{4}{*}{ Spring cereals } & Minimum & 455 & 70 & 1 & 0.6 \\
\hline & Average & 748 & 446 & 36 & 7.7 \\
\hline & Maximum & 1143 & 991 & 212 & 39.6 \\
\hline & Std. dev. & 189 & 249 & 33 & 5.0 \\
\hline \multirow[t]{4}{*}{ Winter cereals } & Minimum & 504 & 115 & 1 & 0.6 \\
\hline & Average & 736 & 424 & 33 & 8.2 \\
\hline & Maximum & 1143 & 988 & 135 & 39.0 \\
\hline & Std. dev. & 142 & 202 & 27 & 6.2 \\
\hline
\end{tabular}


Table 5

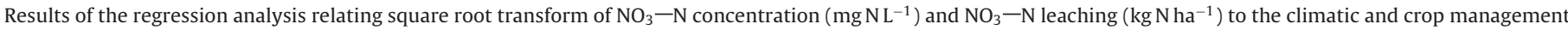
parameters for winter and spring cereals.

\begin{tabular}{|c|c|c|c|c|}
\hline & \multicolumn{2}{|c|}{$\sqrt{\text { Nitrate concentration }}$} & \multicolumn{2}{|c|}{$\sqrt{\text { Nitrate leaching }}$} \\
\hline & Winter cereals & Spring cereals & Winter cereals & Spring cereals \\
\hline$R^{2}$ & 0.62 & 0.47 & 0.68 & 0.77 \\
\hline RMSE & 0.64 & 0.62 & 1.29 & 1.23 \\
\hline Intercept & $-2.25^{\mathrm{NS}}$ & $1.72^{* * *}$ & $-6.44^{*}$ & $-2.71^{* * *}$ \\
\hline \multicolumn{5}{|l|}{ Temperature $\left({ }^{\circ} \mathrm{C}\right)$} \\
\hline Spring & NS & NS & NS & NS \\
\hline Summer & $0.29^{* * *}$ & NS & $0.41^{* *}$ & NS \\
\hline Autumn & NS & $0.13^{* * *}$ & NS & $0.33^{* * *}$ \\
\hline Winter & $0.16^{* * *}$ & NS & $0.35^{* * *}$ & NS \\
\hline \multicolumn{5}{|l|}{ Precipitation (mm) } \\
\hline Spring & NS & $0.0060^{* * *}$ & $0.0125^{* * *}$ & $0.0220^{* * *}$ \\
\hline Summer & NS & NS & $0.0045^{* *}$ & $0.0074^{* * *}$ \\
\hline Autumn & $0.0044^{* * *}$ & NS & $0.0160^{* * *}$ & $0.0089^{* * *}$ \\
\hline Winter & $-0.0027^{* *}$ & $-0.0026^{* * *}$ & NS & NS \\
\hline \multicolumn{5}{|l|}{ Location $^{\mathrm{a}}$} \\
\hline Foulum & $0.91^{* * *}$ & NS & $1.21^{* *}$ & NS \\
\hline Flakkebjerg & $0.42^{\mathrm{NS}}$ & NS & $0.04^{\mathrm{NS}}$ & NS \\
\hline \multicolumn{5}{|l|}{ Rotation $^{\mathrm{b}}$} \\
\hline R4 & $-0.65^{* * *}$ & NS & $-0.90^{* *}$ & NS \\
\hline Horizon depth $(\mathrm{cm})$ & $0.019^{* * *}$ & NS & $0.034^{* * *}$ & NS \\
\hline \multicolumn{5}{|l|}{ Pre-crop ${ }^{c}$} \\
\hline Grass-clover & $-0.19^{\mathrm{NS}}$ & $0.97^{* * *}$ & $-0.49^{\mathrm{NS}}$ & $2.70^{* * * *}$ \\
\hline Potato & $-1.22^{* * *}$ & - & $-2.10^{* * *}$ & - \\
\hline Pulses & $-0.50^{* *}$ & $0.30^{* * *}$ & $-1.04^{* *}$ & $0.55^{* * *}$ \\
\hline \multicolumn{5}{|l|}{ Cover crop $^{\mathrm{d}}$} \\
\hline Weeds & $-1.22^{* * *}$ & $-0.69^{* * *}$ & $-2.24^{* * *}$ & $-1.19^{* * *}$ \\
\hline Catch crop & $-1.51^{* * *}$ & $-1.39^{* * *}$ & $-3.06^{* * *}$ & $-2.86^{* * *}$ \\
\hline Grass-clover & - & $-1.37^{* * *}$ & - & $-2.67^{* * *}$ \\
\hline
\end{tabular}

Significance levels: ${ }^{* * *} P<0.001,{ }^{* *} P<0.01,{ }^{*} P<0.05$, NS not significant.

$R^{2}$ is coefficient of determination and RMSE is root mean squared error of the estimated regression equation.

a Relative to Jyndevad.

b Relative to rotation $\mathrm{R} 2$.

c Relative to cereals as pre-crop.

d Relative to bare soil.

significant positive effect of precipitation during spring on $\mathrm{N}$ concentration.

Temperature during winter and summer had positive effects on $\mathrm{N}$ concentration for winter cereals $(P<0.01)$. For spring cereals only temperature during autumn was found to have a significant $(P<0.001)$ positive effect on $\mathrm{N}$ concentration.

\subsection{Nitrate leaching}

Average $\mathrm{N}$ leaching for winter cereals varied considerably between years, from $17 \mathrm{~kg} \mathrm{Nha}^{-1}$ in $2007 / 2008$ to $63 \mathrm{~kg} \mathrm{Nha}^{-1}$ in $1997 / 1998$ (Fig. 2b). This was due partly to differences in the amount of percolation and to the long-term effects of crop management. The same trend was also observed for spring cereals. On average, $\mathrm{NO}_{3}-\mathrm{N}$ leaching for both cropping systems was close to the mean $\mathrm{N}$ leaching of $34 \mathrm{~kg} \mathrm{Nha}^{-1} \mathrm{y}^{-1}$ measured in Danish arable systems at standard $\mathrm{N}$ fertilizer rate (Simmelsgaard, 1998) (Table 4).

The regression model suggested that $\mathrm{N}$ leaching from winter cereals is significantly affected by location and crop rotation with $\mathrm{N}$ leaching being higher at Jyndevad $\left(45 \mathrm{~kg} \mathrm{~N} \mathrm{ha}^{-1}\right)$. Winter wheat in $\mathrm{R} 4$ tended to have lower $\mathrm{N}$ leaching $\left(21 \mathrm{~kg} \mathrm{~N} \mathrm{ha}^{-1}\right)$ when the crop was grown in systems without grass-clover in the rotation (Table 2) compared to $\mathrm{R} 2$ ( $37 \mathrm{~kg} \mathrm{Nha}^{-1}$ ), as an average of all years and locations. There were also significant effects of the pre-crop and cover crop and the same trends were found as for $\mathrm{N}$ concentration.

Seasonal mean temperature and cumulative precipitation were among the factors that affected $\mathrm{N}$ leaching for both winter and spring cereals (Table 5). Precipitation during autumn, spring and summer significantly $(P<0.001)$ affected $\mathrm{N}$ leaching for both winter and spring cereals with the cumulative precipitation during autumn and spring having the greatest effect on $\mathrm{N}$ leaching for winter and spring cereals, respectively. In contrast to nitrate- $\mathrm{N}$ concentration, precipitation during winter had no significant effect on $\mathrm{N}$ leaching. However, $\mathrm{N}$ leaching followed the same response as $\mathrm{N}$ concentration to seasonal temperatures with temperature during winter and summer having a significant effect for winter cereals and temperatures during autumn having a highly significant effect on $\mathrm{N}$ leaching for spring cereals.

\subsection{Sensitivity and scenario analysis}

$\mathrm{NO}_{3}-\mathrm{N}$ concentration and $\mathrm{NO}_{3}-\mathrm{N}$ leaching were estimated using the derived regression equations for a range of temperature and precipitation changes. Since little variation in temperature was recorded during spring and summer (Table 2), only the temperature during autumn and winter were varied in the sensitivity analyses and therefore the delta change approach was only applied to the daily temperature for these two seasons. However, the delta change approach was applied to precipitation records for all seasons. The crop specific responses in terms of $\mathrm{NO}_{3}-\mathrm{N}$ concentration and leaching to changes in temperature are illustrated in Fig. 3 while responses to changes in precipitation are given in Fig. 4.

For the baseline (BL) temperature the simulated mean $\mathrm{N}$ concentration was slightly higher for winter cereals $\left(8.2 \mathrm{mg} \mathrm{L}^{-1}\right)$ than for spring cereals ( $7.6 \mathrm{mg} \mathrm{L}^{-1}$ ) (Fig. 3a). A rise in mean temperatures above $\mathrm{BL}\left(+1\right.$ to $\left.+4^{\circ} \mathrm{C}\right)$ increased $\mathrm{N}$ concentration for both cropping systems by an average of $0.9 \mathrm{mg} \mathrm{L}^{-1}$ for each increase of $1{ }^{\circ} \mathrm{C}$ for winter cereals, but only by about $0.07 \mathrm{mg} \mathrm{L}^{-1}$ for each increase of $1{ }^{\circ} \mathrm{C}$ for spring cereals. The average total $\mathrm{N}$ leached for BL conditions was slightly higher for spring cereals ( $\left.36 \mathrm{~kg} \mathrm{~N} \mathrm{ha}^{-1}\right)$ compared with winter cereals ( $33 \mathrm{~kg} \mathrm{Nha}^{-1}$ ) (Fig. $3 \mathrm{~b}$ ), and increased on average 

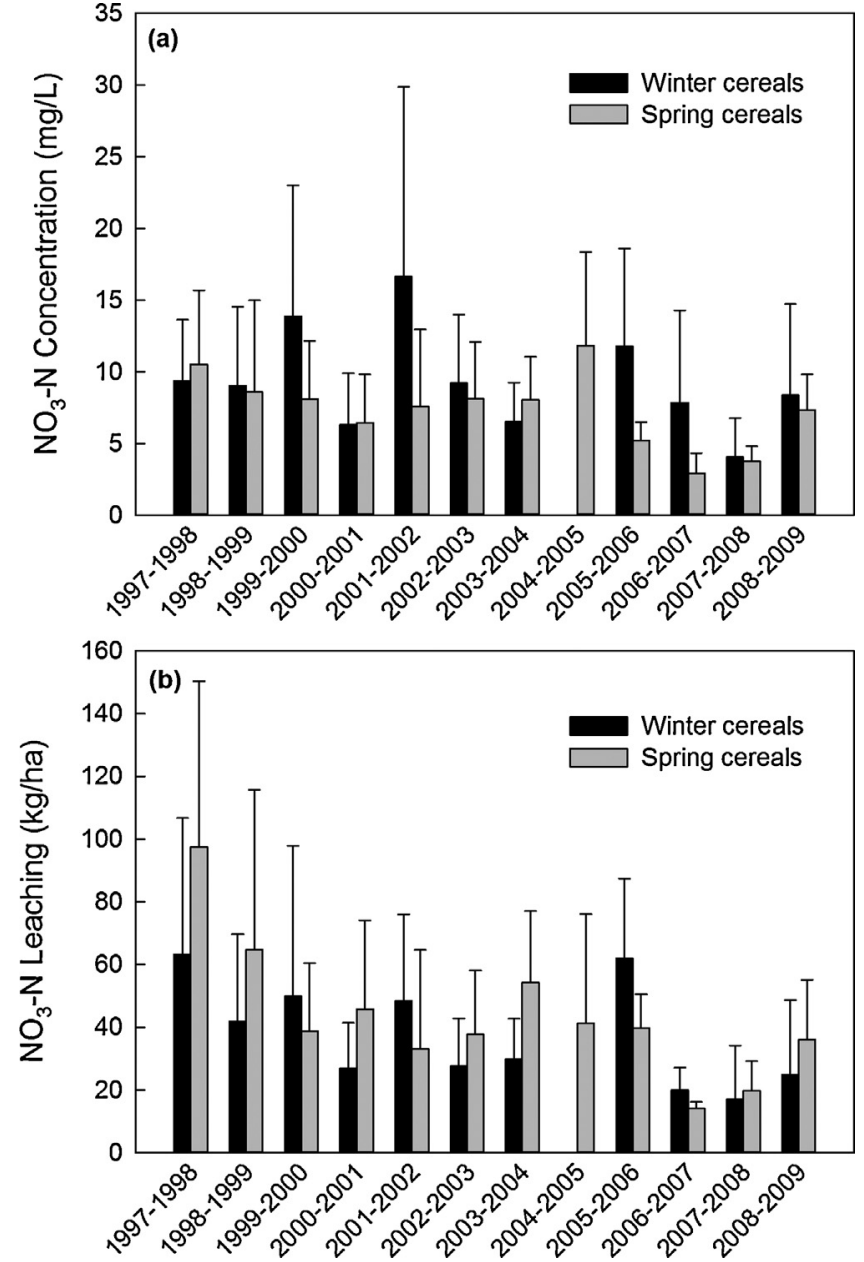

Fig. 2. Average across all locations and all rotations of (a) the annual mean of $\mathrm{NO}_{3}-\mathrm{N}$ concentrations ( $\mathrm{mg} \mathrm{L}^{-1}$ ) and (b) the annual cumulated $\mathrm{NO}_{3}-\mathrm{N}$ leaching $\left(\mathrm{kg} \mathrm{N} \mathrm{ha}^{-1}\right)$ in the leaching periods $1997 / 98$ to $2008 / 09$ (in 2004/05, the winter cereal was replaced by spring barley). Error bars show standard error.

by about $4 \mathrm{~kg} \mathrm{Nha}^{-1}$ for both winter and spring cereals for each increase of $1^{\circ} \mathrm{C}$.

Changes to seasonal precipitation also affected $\mathrm{N}$ concentration for the two cereal types (Fig. 4a). $\mathrm{N}$ concentration in percolated water was predicted to increase ( 7.3 to $9 \mathrm{mg} \mathrm{L}^{-1}$ ) with increasing seasonal precipitation for winter cereals. Similarly, increasing precipitation was predicted to consistently increase $\mathrm{N}$ concentration for spring cereals with an absolute change of about $0.5 \mathrm{mg} \mathrm{L}^{-1}$ for each $20 \%$ change in the precipitation amount. The response of $\mathrm{N}$ leaching to changes in precipitation amount followed the same trend for the two cereal types, although the extent of the response differed slightly (Fig. 4b). For winter cereals, the N leaching increased by approximately $13 \mathrm{~kg} \mathrm{Nha}^{-1}$ for each increase of $20 \%$ of precipitation; whereas it increased on average by about $15 \mathrm{~kg} \mathrm{~N} \mathrm{ha}^{-1}$ for spring cereals. Therefore, increased precipitation is predicted to lead to higher $\mathrm{N}$ leaching, in particular $\left(>60 \mathrm{~kg} \mathrm{~N} \mathrm{ha}^{-1}\right)$ for precipitation increases at $+40 \%$ above current amount.

\section{Discussion}

\subsection{Management effects}

The models indicated that site, soil properties, preceding crop, crop rotation, and crop cover during autumn and winter all contributed significantly to soil nitrate concentration and leaching for winter and spring cereals; hence corroborating the findings of Askegaard et al. (2005, 2011). A substantial part of the variation for winter wheat was clearly related to location. In fact, location had a significant effect on nitrate concentration, with Foulum (loamy sand) and Flakkebjerg (sandy loam) having the largest effect on concentrations compared to the coarse sandy soil at Jyndevad. The same trends were obtained for $\mathrm{N}$ leaching. The larger $\mathrm{N}$ leaching from Foulum is likely linked to a higher initial soil organic matter content at this site giving rise to a higher rate of soil $\mathrm{N}$ mineralization (Olesen et al., 2007b). Some of the effects may also be linked with differences in management. For instance spring ploughing was used at Jyndevad and Foulum before spring crops, whereas winter ploughing was used at Flakkebjerg (Askegaard et al., 2011). Also, $\mathrm{NO}_{3}-\mathrm{N}$ concentrations were measured using suction cells at $80 \mathrm{~cm}$ depth at Jyndevad and $100 \mathrm{~cm}$ depth at Foulum and Flakkebjerg which might have contributed to the location differences.

The statistical model in Table 5 included a response to A horizon depth, which varied between 27 and $93 \mathrm{~cm}$, being most shallow at Jyndevad and with considerable variation within sites at both Foulum and Flakkebjerg (Table 1). The depth of the A-horizon was thus found to be important for explaining nitrate concentration in percolated water for winter cereals. As the A-horizon defines the upper soil horizon containing most of the soil organic matter and in which most of the biological activity occurs, greater $\mathrm{N}$ mineralization could be expected with greater A-horizon depth which, in turn, could elevate $\mathrm{N}$ leaching. In accordance with this, Petersen et al. (2012), studying the same rotations, identified the depth of the A horizon as a contributing factor for $\mathrm{N}$ supply of winter wheat under organic farming.

Moreover, significant effects of crop rotation and previous crop were identified by the mixed model to contribute significantly to the nitrate concentration and nitrate leaching from winter and spring cereals. Growing grass-clover as pre-crop resulted in high levels of $\mathrm{N}$ leaching, especially for spring cereals $\left(87 \mathrm{~kg} \mathrm{Nha}^{-1}\right)$ compared to winter cereals $\left(41 \mathrm{~kg} \mathrm{Nha}^{-1}\right)$. This is mainly due to the plough-in of the grass-clover in spring prior to sowing spring cereals, thus moving the main $\mathrm{N}$ leaching from the winter period prior to the growing season to the autumn and winter following the cereal growing season. Similar results were found by Askegaard et al. (2005, 2011). Simmelsgaard (1998) also found crop type to be the most important factor influencing $\mathrm{N}$ leaching with high rates of leaching from winter cereals following oilseed rape or peas. Similarly, significant effects of the crop sequences on $\mathrm{N}$ leaching were found by Sieling and Kage (2006), who observed larger N losses with winter wheat following oilseed rape than with oilseed rape following spring barley. The type of the preceding crop affects the amount of residual $\mathrm{N}$ during autumn available for leaching. Francis et al. (1994) reported from an experiment using rotations with legume and non-legume crops and spring crops that the amount of mineral $\mathrm{N}$ remaining in the soil profile in the autumn after harvest of barley and rapeseed crops was about $52 \mathrm{~kg} \mathrm{~N} \mathrm{ha}^{-1}$. However, after leguminous crops, the residual $\mathrm{N}$ was generally larger (mean of $80 \mathrm{~kg} \mathrm{Nha}^{-1}$ ).

Furthermore, our study shows reduced $\mathrm{N}$ leaching when a catch crop is grown during autumn and winter. In fact, the use of catch crops, when averaged for all years, reduced $\mathrm{NO}_{3}-\mathrm{N}$ leaching by 41 to $63 \%$ for winter cereals and by 7 to $55 \%$ for spring cereals compared to when the soil is kept un-cropped (weeds or bare soil) in the autumn after harvest of the cereal. Therefore, including catch crops in cereal-based cropping systems may help extend soil cover in autumn and winter and take up additional $\mathrm{N}$ left over in the soil after early harvest of the cereal crop (Thomsen et al., 2010). The effect of such short-season catch crops in reducing N leaching corroborates the findings of Ritter et al. (1998), Shepherd (1999), Blombäck et al. (2003) and Doltra and Olesen (2013). All the above results highlight the potential of catch crops in 

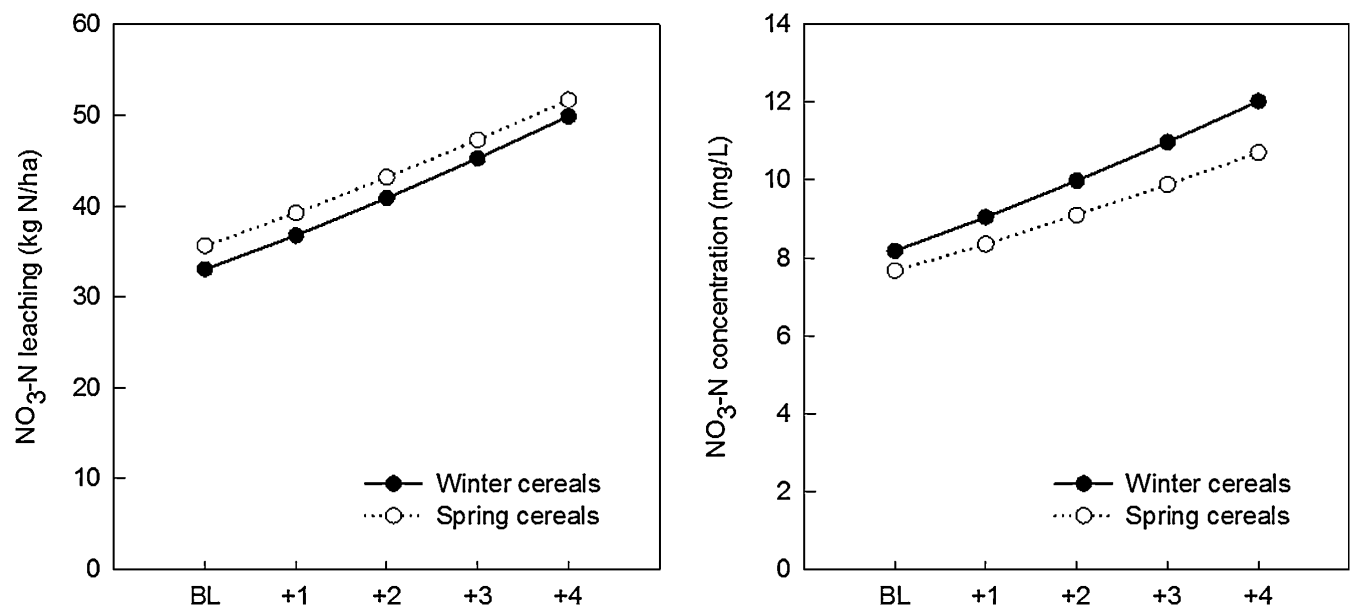

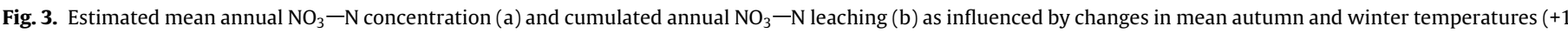
to $+4{ }^{\circ} \mathrm{C}$ above baseline; $\mathrm{BL}$ ) for winter and spring cereals using the regression equations.
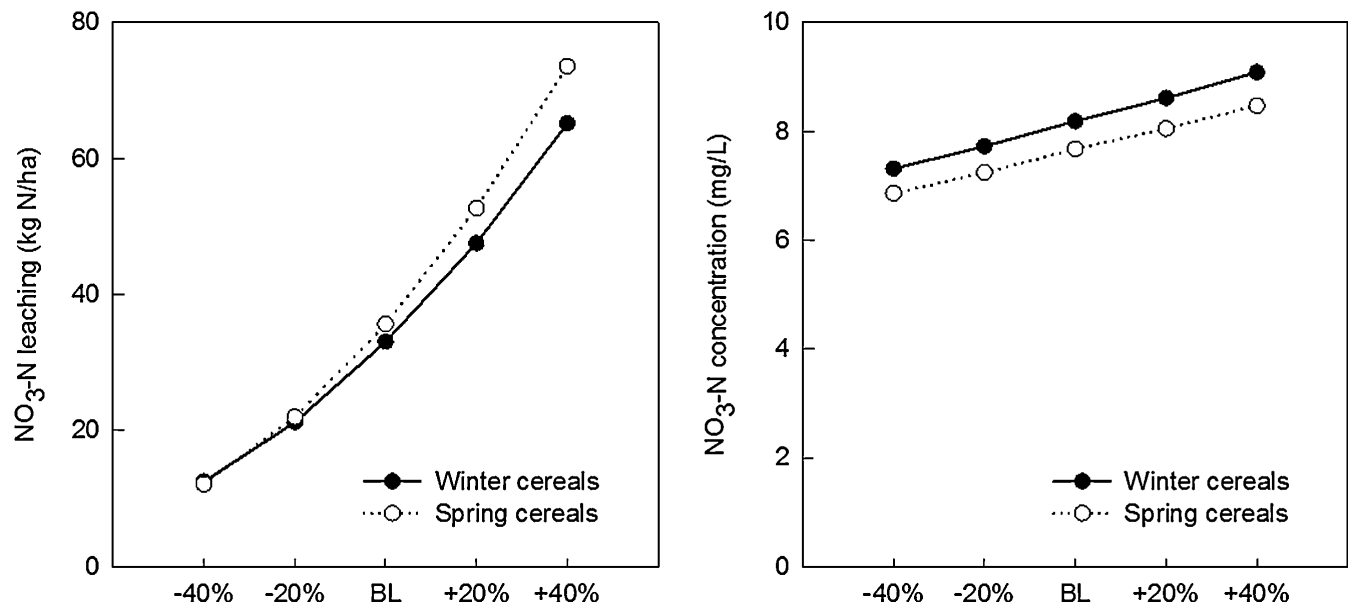

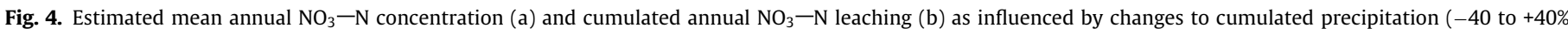
below/above baseline; $\mathrm{BL}$ ) for winter and spring cereals using the regression equations.

autumn/winter in reducing the annual N leaching in cereal cropping systems.

\subsection{Climate effects}

There were highly significant effects of seasonal average temperature and cumulated precipitation on nitrate concentration and leaching for the two cropping systems. No interaction between air temperature and precipitation were found to significantly affect $\mathrm{N}$ leaching or $\mathrm{N}$ concentration, though. However, many studies have shown that such interaction is important for $\mathrm{N}$ mineralization (Knoepp and Swank, 2002; Cabrera et al., 2005), and likely also for $\mathrm{N}$ leaching. In our projections of $\mathrm{N}$ leaching, we did not account for such interactions, and the application of our regression models for extrapolating $\mathrm{N}$ leaching should therefore be interpreted with due caution.

The climatic effects highlighted in this study are in accordance with model-based studies of climate change impacts on $\mathrm{N}$ leaching from cereal cropping systems in Denmark (Børgesen and Olesen, 2011; Patil et al., 2012). For instance, Patil et al. (2012), using the FASSET model to evaluate the sensitivity of winter wheat yield and soil $\mathrm{N}$ losses to stepwise changes in mean and variance of climatic variables in Denmark, showed an increase in mineral $\mathrm{N}$ leaching from winter wheat with increasing temperature, in particular for sandy loam soil at temperature increases above $2^{\circ} \mathrm{C}$. They also found higher simulated soil mineral $\mathrm{N}$ concentrations after crop harvest in summer and, therefore, higher risk of $\mathrm{NO}_{3}-\mathrm{N}$ leaching during autumn and winter, which was ascribed to less $\mathrm{N}$ uptake by the crop and increased mineral $\mathrm{N}$ in soil profiles. The increased soil mineral $\mathrm{N}$ could be mostly attributed to climatic factors, in particular temperature that enhances mineralization processes through effects on soil microbial activity (Leirós et al., 1999; Emmett et al., 2004; Patil et al., 2010). In a synthesis of results from 32 studies on attempting to predict the influence of climate changes on terrestrial ecosystems, temperature increase of $2.4{ }^{\circ} \mathrm{C}$ was found to increase soil respiration by $20 \%$, whereas net $\mathrm{N}$ mineralization rates increased by $46 \%$ (Rustad et al., 2001).

Based on our results, we conjecture that precipitation plays crucial role in explaining variations in nitrate concentration and leaching. Precipitation strongly increased N leaching, except for the winter season when precipitation apparently did not affect $\mathrm{N}$ leaching for neither spring nor winter cereals. This agree with Patil et al. (2012) who found that an increase in winter precipitation had less impact on $\mathrm{N}$ leaching than summer precipitation. During winter, it was also found that high rates of precipitation correlate negatively with $\mathrm{NO}_{3}-\mathrm{N}$ concentration for the two cereal cropping systems which could partly explain the non-significant effect on $\mathrm{N}$ leaching. This may be ascribed to the dilution effect (Beaudoin et al., 2005), where a fixed source of $\mathrm{N}$ is diluted by increasing amounts of precipitation. An additional reason for reduced $\mathrm{N}$ concentration during 
winter might be enhanced denitrification induced by temporary anaerobic conditions under saturated soil conditions. Potential denitrification rate is predominantly (given suitable temperatures) determined by high nitrate concentrations in soil solution and by high soil moisture content which is likely to happen during the winter season (Blombäck et al., 2003; Martínková et al., 2011; Sänger et al., 2011).

Our findings provide clear indications that higher temperature during winter and summer would increase $\mathrm{NO}_{3}-\mathrm{N}$ concentration and leaching for winter cereals which could be attributed to an increase in soil mineralization rates as suggested by Wick et al. (2012). With increased temperatures, soil organic matter turnover increases and this potentially increases available soil mineral $\mathrm{N}$, thus amplifying the risk of $\mathrm{N}$ leaching (Børgesen and Olesen, 2011). Moreover, we believe that changes in air temperature will also involve changes in planting and harvesting times as well as in fertilization rates and strategies (Doltra et al., 2014), which will also affect nitrate leaching. Later planting and earlier harvest of winter cereals may result in a prolonged period of bare soil in autumn, which will increase the risk of N leaching (Patil et al., 2012), particularly in connection with increased autumn and winter precipitation.

\subsection{Implications for crop management}

Several studies have addressed the effects of climate change on $\mathrm{N}$ leaching of crops like winter wheat and spring barley in Denmark (Olesen et al., 2007a; Patil et al., 2012; Doltra et al., 2014). Conclusions from these studies support the general notion that $\mathrm{N}$ leaching from cereal cropping systems may increase substantially in response to projected climate change. The current study provides additional empirical evidence that nitrate concentration and nitrate leaching under cereal cropping systems will be increased by projected changes in temperature and precipitation under anthropogenic climate change. Warming is expected to increase soil organic matter turnover, provided sufficient water is available. Warming may further increase the duration of the period in autumn with bare soil due to a shorter growing period under a warmer climate (Olesen et al., 2011) that in combination with increased soil $\mathrm{N}$ mineralization and increased precipitation may increase the risk of $\mathrm{N}$ leaching.

Our results show that nitrate concentration and leaching are site-specific and vary substantially with crop and soil management. Growing catch crops during autumn and winter has been shown to reduce $\mathrm{N}$ leaching. The ability of catch crops to absorb mineral $\mathrm{N}$ from the soil profile is affected by their root growth rate and depth (Vos et al., 1998; Sapkota et al., 2012). However, many studies have reported that incorporation of straw, together with $\mathrm{N}$-rich aboveground biomass of catch crops promoted immobilization of soil mineral $\mathrm{N}$, restored soil organic matter and improved aeration (Talgre et al., 2011). This increased fertility, besides improving cash crop yields, might increase $\mathrm{N}$ losses through leaching or gaseous emissions, thereby stressing the importance of studying the effect of catch crop use and crop residue management on a long-term basis (Berntsen et al., 2006). Current catch crop management schemes (e.g. plant species, sowing date) might not be sufficient to avoid the potential future increase in $\mathrm{N}$ leaching. The choice of the most convenient strategy would be site and rotationspecific, and should be combined with an efficient schedule and application of fertilizers and manure handling according to the rotation requirements (Doltra et al., 2014). Therefore, further studies must be conducted to identify suitable crop rotation and soil and crop management techniques to prevent increased nitrate leaching under projected climate change. Further studies on the effects of climate change on soil $\mathrm{N}$ turnover and $\mathrm{N}$ losses are thus needed. There is a particular need to further study how long-term changes in soil organic $\mathrm{N}$ levels as affected by climate change may affect $\mathrm{N}$ leaching potential.

\section{Conclusions}

Climate changes such as changes in temperature, precipitation amounts and distribution will have an impact on soil processes which are likely to lead to increased nitrate leaching from the soil. This has so far mainly been supported by model-based studies. Our independent statistical analyses of a 12-year field trial at three locations in Denmark support these findings. Over the 12year study period, nitrate concentration and leaching were shown to be driven by soil and climatic factors and by crop and soil management effects. $\mathrm{N}$ concentration and leaching losses from the crop rotations strongly depended on field management during autumn and the impact of climate change on $\mathrm{N}$ concentrations and leaching appears to be driven by seasonal changes in temperature and precipitation for the two studied cropping systems. Precipitation during spring, summer and autumn all enhanced $\mathrm{N}$ leaching for both spring and winter cereals, whereas winter precipitation had no significant effect. $\mathrm{N}$ leaching was mostly affected by temperature during winter for winter cereals and during autumn for spring cereals, and in both cases higher temperatures enhanced $\mathrm{N}$ leaching. The predicted changes in $\mathrm{N}$ concentration and leaching were found to increase with increases in temperature and precipitation and the amount of $\mathrm{N}$ leaching was found to be lower when a catch crop was grown during autumn and winter than when the soil was left bare. Therefore, effective crop $\mathrm{N}$ uptake during autumn and winter seems to be essential for reducing $\mathrm{N}$ leaching under climate change.

\section{Acknowledgements}

This study was financially supported by Aarhus University and by the Sino-Danish University Centre for Education and Research. It was further linked to the CRES Centre funded by the Danish Council for Strategic Research under contract no: DSF-EnMi 09-066868.

\section{References}

Allen, M.R., Ingram, W.J., 2002. Constraints on future changes in climate and the hydrologic cycle. Nature 419, 224-232.

Askegaard, M., Olesen, J.E., Kristensen, K., 2005. Nitrate leaching from organic arable crop rotations: effects of location, manure and catch crop. Soil Use Manage. 21, 181-188.

Askegaard, M., Olesen, J.E., Rasmussen, I.A., Kristensen, K., 2011. Nitrate leaching from organic arable crop rotations is mostly determined by autumn field management. Agric. Ecosyst. Environ. 142, 149-160.

Beaudoin, N., Saad, J., Van Laethem, C., Machet, J., Maucorps, J., Mary, B., 2005. Nitrate leaching in intensive agriculture in Northern France: effect of farming practices, soils and crop rotations. Agric. Ecosyst. Environ. 111, 292-310.

Berntsen, J., Olesen, J.E., Petersen, B.M., Hansen, E.M., 2006. Long-term fate of nitrogen uptake in catch crops. Eur. J. Agron. 25, 383-390.

Bindi, M., Olesen, J.E., 2011. The responses of agriculture in Europe to climate change. Reg. Environ. Change 11, 151-158.

Blombäck, K., Eckersten, H., Lewan, E., Aronsson, H., 2003. Simulations of soil carbon and nitrogen dynamics during seven years in a catch crop experiment. Agric. Syst. 76, 95-114.

Børgesen, C., Olesen, J.E., 2011. A probabilistic assessment of climate change impacts on yield and nitrogen leaching from winter wheat in Denmark. Nat. Hazard. Earth Syst. Sci. 11, 2541-2553.

Cabrera, M., Kissel, D., Vigil, M., 2005. Nitrogen mineralization from organic residues: research opportunities. J. Environ. Qual. 34, 75-79.

Contosta, A., Frey, S., Cooper, A., 2011. Seasonal dynamics of soil respiration and N mineralization in chronically warmed and fertilized soils. Ecosphere 2, 1-21.

Djurhuus, J., Olesen, J.E., 2000. Characterisation of four sites in Denmark for longterm experiments on crop rotations in organic farming. In: DIAS Report 33 Danish Institute of Agricultural Sciences, Research Centre Foulum, PO Box 50, DK-8830, Tjele, pp. 74 pp.

Doltra, J., Olesen, J.E., 2013. The role of catch crops in the ecological intensification of spring cereals in organic farming under Nordic climate. Eur. J. Agron. 44, 98-108.

Doltra, J., Lægdsmand, M., Olesen, J.E., 2014. Impacts of projected climate change on productivity and nitrogen leaching of crop rotations in arable and pig farming systems in Denmark. J. Agric. Sci. 152, 75-92. 
Emmett, B.A., Beier, C., Estiarte, M., Tietema, A., Kristensen, H.L., Williams, D., Penuelas, J., Schmidt, I., Sowerby, A., 2004. The response of soil processes to climate change: results from manipulation studies of shrublands across an environmental gradient. Ecosystems 7, 625-637.

Francis, G.S., Haynes, R.J., Williams, P.H., 1994. Nitrogen mineralization, nitrate leaching and crop growth after ploughing-in leguminous and non-leguminous grain crop residues. J. Agric. Sci. 123, 81-87.

Hansen, B., Kristensen, E.S., Grant, R., Høgh-Jensen, H., Simmelsgaard, S.E., Olesen, J.E., 2000a. Nitrogen leaching from conventional versus organic farming systems-a systems modelling approach. Eur. J. Agron. 13, 65-82.

Hansen, E.M., Djurhuus, J., Kristensen, K., 2000b. Nitrate leaching as affected by introduction or discontinuation of cover crop use. J. Environ. Qual. 29, 1110-1116.

Hatfield, J., Singer, J., 2011. Climate change: what to expect and how will it affect feedstock production options? In: Brown, R., Karlen, D., Johnson, D. (Eds.), Sustainable Biofuels for Advanced Biofuels. Soil and Water Conservation Society, pp. 349-360.

Jeppesen, E., Kronvang, B., Olesen, J.E., Audet, J., Søndergaard, M., Hoffmann, C.C., Andersen, H.E., Lauridsen, T.L., Liboriussen, L., Larsen, S.E., Beklioglu, M., Meerhoff, M., Özen, A., Özkan, K., 2011. Climate change effects on nitrogen loading from cultivated catchments in Europe: implications for nitrogen retention, ecological state of lakes and adaptation. Hydrobiologia 663, 1-21.

Knoepp, J.D., Swank, W.T., 2002. Using soil temperature and moisture to predict forest soil nitrogen mineralization. Biol. Fertil. Soils 36, 177-182.

Kronvang, B., Andersen, H.E., Børgesen, C., Dalgaard, T., Larsen, S.E., Bøgestrand, J., Blicher-Mathiasen, G., 2008. Effects of policy measures implemented in Denmark on nitrogen pollution of the aquatic environment. Environ. Sci. Policy $11,144-152$.

Leirós, M., Trasar-Cepeda, C., Seoane, S., Gil-Sotres, F., 1999. Dependence of mineralization of soil organic matter on temperature and moisture. Soil Biol. Biochem. 31, 327-335.

Lord, E., Shepherd, M., 1993. Developments in the use of porous ceramic cups for measuring nitrate leaching. J. Soil Sci. 44, 435-449.

Martínková, M., Hesse, C., Krysanova, V., Vetter, T., Hanel, M., 2011. Potential impact of climate change on nitrate load from the Jizera catchment (Czech Republic). Phys. Chem. Earth 36, 673-683.

Nielsen, A., Trolle, D., Søndergaard, M., Lauridsen, T.L., Bjerring, R., Olesen, J.E., Jeppesen, E., 2012. Watershed land use effects on lake water quality in Denmark. Ecol. App. 22, 1187-1200.

Olesen, J.E., Heidmann, T., 1990. EVACROP. Et program til beregning af aktuel fordampning og afstrømning fra rodzonen (A program for calculating actual evapotranspiration and drainage from the root zone). In: Version 1.01. AJMET Arbejdsnotat, No. 9. Forskningscenter Foulum, Statens PlanteavlsForsøg (in Danish).

Olesen, J.E., Jensen, T., Petersen, J., 2000a. Sensitivity of field-scale winter wheat production in Denmark to climate variability and climate change. Clim. Res. 15, 221-238.

Olesen, J.E., Askegaard, M., Rasmussen, I.A., 2000b. Design of an organic farming crop-rotation experiment. Acta Agric. Scand. Sec. B-Plant Soil Sci. 50, 13-21.

Olesen, J.E., Rubæk, G.H., Heidmann, T., Hansen, S., Børgensen, C.D., 2004. Effect of climate change on greenhouse gas emissions from arable crop rotations. Nutr. Cycl. Agroecosyst. 70, 147-160.

Olesen, J.E., Carter, T., Diaz-Ambrona, C., Fronzek, S., Heidmann, T., Hickler, T., Holt, T., Minguez, M., Morales, P., Palutikof, J., Quemada, M., Ruiz-Ramos, M., Rubæk, G., Sau, F., Smith, B., Sykes, M., 2007a. Uncertainties in projected impacts of climate change on European agriculture and terrestrial ecosystems based on scenarios from regional climate models. Clim. Change 81, 123-143.

Olesen, J.E., Hansen, E.M., Askegaard, M., Rasmussen, I.A., 2007b. The value of catch crops and organic manures for spring barley in organic arable farming. Field Crops Res. 100, 168-178.

Olesen, J.E., Trnka, M., Kersebaum, K., Skjelvåg, A., Seguin, B., Peltonen-Sainio, P., Rossi, F., Kozyra, J., Micale, F., 2011. Impacts and adaptation of European crop production systems to climate change. Eur. J. Agron. 34, 96-112.
Orlandini, S., Nejedlik, P., Eitzinger, J., Alexandrov, V., Toulios, L., Calanca, P., Trnka M., Olesen, J.E., 2008. Impacts of climate change and variability on European agriculture. Ann. N.Y. Acad. Sci. 1146, 338-353.

Patil, R.H., Laegdsmand, M., Olesen, J.E., Porter, J.R., 2010. Effect of soil warming and rainfall patterns on soil N cycling in Northern Europe. Agric. Ecosyst. Environ. 139, 195-205.

Patil, R.H., Laegdsmand, M., Olesen, J.E., Porter, J.R., 2012. Sensitivity of crop yield and $\mathrm{N}$ losses in winter wheat to changes in mean and variability of temperature and precipitation in Denmark using the FASSET model. Acta Agric. Scand. Sect. B-Soil Plant Sci. 62, 335-351.

Petersen, S.O., Schjønning, P., Olesen, J.E., Christensen, S., Christensen, B.T., 2012 Sources of nitrogen for winter wheat in organic cropping systems. Soil Sci. Soc. Am. J. 77, 155-165.

Piepho, H.P., Büchse, A., Emrich, K., 2003. A hitchhiker's guide to mixed models for randomized experiments. J. Agron. Crop Sci. 189, 310-322.

Pinheiro, J., Bates, D., DebRoy, S., Sarkar, D., Team, R.C., 2012. nlme: linear and nonlinear mixed effects models. In: R Package Version 3., pp. 105.

Ritcey, A.C., Wu, Y.S., 1999. Evaluation of the effect of future climate change on the distribution and movement of moisture in the unsaturated zone at Yucca Mountain, NV. J. Contam. Hydrol. 38, 257-279.

Ritter, W., Scarborough, R., Chirnside, A., 1998. Winter cover crops as a best management practice for reducing nitrogen leaching. J. Contam. Hydrol. 34 $1-15$.

Rustad, L., Campbell, J., Marion, G., Norby, R., Mitchell, M., Hartley, A., Cornelissen, J., Gurevitch, J., 2001. A meta-analysis of the response of soil respiration, net nitrogen mineralization, and aboveground plant growth to experimental ecosystem warming. Oecologia 126, 543-562.

Sapkota, T.B., Askegaard, M., Lægdsmand, M., Olesen, J.E., 2012. Effects of catch crop type and root depth on nitrogen leaching and yield of spring barley. Field Crops Res. 125, 129-138.

Shepherd, M.A., 1999. The effectiveness of cover crops during eight years of a UK sandland rotation. Soil Use Manage. 15, 41-48.

Sieling, K., Kage, H., 2006. $\mathrm{N}$ balance as an indicator of $\mathrm{N}$ leaching in an oilseed rape-winter wheat-winter barley rotation. Agric. Ecosyst. Environ. 115 $261-269$.

Simmelsgaard, S.E., 1998. The effect of crop, N-level, soil type and drainage on nitrate leaching from Danish soil. Soil Use Manage. 14, 30-36.

Sänger, A., Geisseler, D., Ludwig, B., 2011. Effects of moisture and temperature on greenhouse gas emissions and $\mathrm{C}$ and $\mathrm{N}$ leaching losses in soil treated with biogas slurry. Biol. Fertil. Soils 47, 249-259.

Talgre, L., Lauringson, E., Makke, A., Lauk, R., 2011. Biomass production and nutrien binding of catch crops. Žemdirbystè Agric. 98, 251-258.

Tao, F., Zhang, Z., 2011. Impacts of climate change as a function of global mean temperature: maize productivity and water use in China. Clim. Change 105, 409-432.

Thomsen, I.K., Lægdsmand, M., Olesen, J.E., 2010. Crop growth and nitrogen turnover under increased temperatures and low autumn and winter light intensity. Agric Ecosyst. Environ. 139, 187-194.

Trnka, M., Olesen, J.E., Kersebaum, K.C., Skjelvåg, A.O., Eitzinger, J., Seguin, B. Peltonen-Sainio, P., Rötter, R., Iglesias, A., Orlandini, S., Dubrovsky, M., Hlavinka, P., Balek, J., Eckersten, H., Cloppet, E., Calanca, P., Rötter, R., Gobin, A., Vucetic V., Nejedlik, P., Kumar, S., Lalic, B., Mestre, A., Rossi, F., Alexandrov, V., Kozyra, J., Schaap, B., Zalud, Z., 2011. Agroclimatic conditions in Europe under climate change. Global Change Biol. 17, 2298-2318.

Vos, J., Van Der Putten, P., Hassan Hussein, M., Van Dam, A., Leffelaar P., 1998. Field observations on nitrogen catch crops. Plant Soil 201, 149-155.

Wick, K., Heumesser, C., Schmid, E., 2012. Groundwater nitrate contamination: factors and indicators. J. Environ. Manage. 111, 178-186.

Zuur, A.F., Ieno, E.N., Elphick, C.S., 2010. A protocol for data exploration to avoid common statistical problems. Meth. Ecol. Evol. 1, 3-14. 